\title{
Affiliation in Higher Education: Roles University Satisfaction and Gender as Moderation
}

\author{
M. Abdi Dzil Ikhram W. ${ }^{1}{ }^{*}$ Wahdiyat Moko² Dunga Dwi Barinta ${ }^{3}$ \\ 1,2,3 Brawijaya University, Indonesia \\ "Corresponding author. Email: abdidzil@ub.ac.id
}

\begin{abstract}
A person's behavior to use a product, symbol, or attribute of an institution is part of the recognition of the institution to which it is affiliated. Comfort and satisfaction can be factors that cause someone to make their institution as an affiliate voluntarily. This phenomenon is often measured in business organizations or companies. The same thing should also be applied to higher education. Universities as providers of higher education services are inseparable from providing satisfaction to students. Student satisfaction can encourage them to volunteer to use university products, attributes, or symbols as their affiliation. This study aims to see the effect of University Satisfaction on University Affiliation by including gender as a moderating variable. 91 respondents from three state universities in Malang City. This study found the influence of University Satisfaction on University Affiliation. Besides, gender differences do not show a moderating relationship in these variables.
\end{abstract}

Keywords: University Satisfaction, University Affiliation, Gender.

\section{INTRODUCTION}

The COVID-19 pandemic has entered its second half, where this pandemic has an impact on all sectors, including the education sector. The Covid-19 pandemic has had an impact on the university affiliate level. The occurrence of the covid-19 pandemic requires the government and universities to issue policies and learning systems that are by existing conditions. University policies that emerged due to the Covid-19 pandemic indirectly also impacted university satisfaction. University policies and learning systems used are one form of service the university provides to students. A sense of dissatisfaction can arise from students when university policies and learning systems during the pandemic are not by the conditions and expectations in students. The emergence of a sense of dissatisfaction will affect the level of university affiliation. Furthermore, previous research explains that the level of service quality provided by the university gives rise to perception both positive and negative perceptions and student satisfaction [6].

University affiliation is needed by higher education institutions or universities [1]. University affiliation can be used as an effective promotional strategy to introduce it to the wider community [2]. The form of university affiliation is shown through students' attitude voluntarily using logos, souvenirs, clothes, and other products that characterize the university [1]. A sense of pride and volunteerism in using products that become the university's identity can indirectly introduce the university to a wider market and reduce the promotional costs that the university must incur [2], [3].

Universities require high promotional costs in marketing educational services. As a non-profit institution as a provider of university education services, it cannot maximize promotional costs. Besides, universities also need to increase costs to increase the value and quality of education [4], [5]. Increasing the value and quality of education at the university will provide a positive experience and be able to increase student pride and satisfaction. The following research conducted by [6] shows that service quality at universities can provide positive perceptions and satisfaction to students.

Satisfaction or university satisfaction can occur when students have positive experiences with the 
services provided by the university. Dimensions in measuring satisfaction are divided into learning facilities, curriculum, teaching and learning, university climate, and administrative facilities [7]. Adopting the Social Exchange Theory theory expressed by [8], the experience gained by a person can change a person's behavior or attitude. If linked to a university affiliation, the attitude shown by students to wear products that become the university's identity, which is an affiliate, can be a behavior change.

This behavior change can be caused by students' feelings of pride and satisfaction. The positive experience that is formed can cause students to feel satisfied; then students can determine the attitude to wear and display products that become the university's identity [9]. [1] developed a university affiliation of [10]. [10] uses affiliation as an attitude shown by employees voluntarily using logos, clothes, or other products that become the company's identity as a feeling of pride and commitment to the company. Furthermore, [1] developed a university affiliation in universities with measurements measured by the willingness of students to wear and display logos, clothes, or products that show the university's identity. One of the reasons for this attitude is university satisfaction.

Research related to university affiliation in higher education or universities is still limited and has not been widely developed. The higher the number of higher education results in a university affiliation that is feasible to be applied in universities as an indirect promotion strategy. Malang is one of the cities in Indonesia has the nickname as the city of education, the number of tertiary education institutions recorded in Malang is 80 universities, and three of them are universities with state status [11]. The State University in Malang is in great demand compared to the others. It is indicated by the number of students at the State University greater than the others. State universities in Malang have students from various regions. It shows that the attractiveness of the State University is quite large [12]. Based on this phenomenon, university affiliation attracts students from outside the region to continue their education in Malang.

Besides, this study also measures the role of gender in moderating university affiliation. Gender differences can help strengthen the role of University Satisfaction with university affiliations. Based on the phenomenon described in this study, university satisfaction in influencing university affiliation is moderated by gender at state universities in Malang. In general, this study aims to provide a view regarding University Affiliation in higher education institutions. In particular, this research was conducted to test and determine university satisfaction has a positive effect on university affiliations and find out how gender roles in moderating the relationship between University Satisfaction and University Affiliation.

\section{LITERATURE REVIEW}

\subsection{University Affiliation}

University affiliation is an attitude shown by students voluntarily using something related to their university. Views used by students in a university such as logos, stickers, souvenirs, and other items that can become the identity of the university[1]. The concept of university affiliation used by [1] adopted the research of [10], which states that a person's commitment can be measured through their attitude in using and displaying something related to their institution. The voluntary use of university products by students will positively impact the university. It also promotes the university to the wider community without incurring promotional costs. [2] stated that using goods or clothing with logos has a positive relationship with promotional strategies. Besides, [13] stated that the university's success is shown through the use of clothes with a logo that shows a sense of belonging to the university.

Students need their motivation to voluntarily change their behavior in using products that become the identity of their university. Students' positive and negative behavior changes will affect commitment to achieving goals[9]. The social exchange theory states that students' dependence on universities can be influenced by the experiences gained in universities [8]. The experience gained can be a strength and motivation for students in using products related to the university.

\subsection{University Satisfaction}

Satisfaction is one of the things that motivates students to use and display the university's logo. Students' satisfaction can come from the experience gained with the use of services and products owned by the university. Service and product quality in higher education is a complex and multifaceted concept [14]. Students receive and use the training 
offered by the university, which makes them a priority customer of educational activities [15]. [16][18] also consider students to be the primary consumers of higher education services. Research related to satisfaction in higher education is still limited, [15] showed that student satisfaction is a complex concept and consists of several dimensions. Referring to [19] definition of satisfaction, [20], describe student satisfaction as "students' subjective evaluations of preferences for outcomes and experiences related to education. Student satisfaction continues to be shaped by repeated experiences in campus life". Student feedback can positively influence the quality of service at educational institutions as well as support the university in several ways. [7] states that dimensions in measuring satisfaction are divided into learning facilities, curriculum, teaching and learning, university climate, and administrative facilities. The positive experience that is formed can cause students to feel satisfied, then students can determine the attitude to wear and display products that become the identity of the university [9].

The research results of [1] suggest that universities should pay attention to students and see this as something that has the potential to improve students' social, learning, and psychological environment. The involvement of students with the university through the experiences gained will build personal relationships and behaviors that support the university. The positive experiences that students feel about using the services and facilities available at the university can encourage student satisfaction. The attitudes and behaviors shown by the experience felt by these students encourage students to voluntarily display and show the identity of the university they are affiliated with. Student satisfaction and behavior in using university products are gaps in this study. Besides, this study will also look at gender differences in using and displaying something that identifies the university to which it is affiliated, thus the proposed hypothesis is as follows:

H1: University Satisfaction will have a positive influence on University Affiliation

H2: Gender moderates the relationship between University Satisfaction and University Affiliation

\section{RESEARCH METHOD}

This research is quantitative research with an explanatory approach. This research was conducted at Brawijaya University, Malang State University, and Maulana Malik Ibrahim University in Malang City. The population in this study were students who studied at Brawijaya University, Malang State University, and Maulana Malik Ibrahim University by using a sampling technique, namely convenience sampling. There are several indicators used in this research variable. Measurement of university satisfaction variables refers to research by [6] and [7]. [6] measure university satisfaction with 10 indicators. [7] in further research develop measurements of university satisfaction in 6 dimensions consisting of learning facilities, curricula, teaching \& learning, university climate, administrative facilities, and policies and procedures. The university affiliation variable was measured using 3 statement items that were adopted in [10] and [1]. Overall statement items used in this study were 35 statement items.

Retrieval of data in this study using a questionnaire with a Linkert scale, a scale of 1-5. The distribution of questionnaires was carried out online due to the constraints of the Covid-19 pandemic so that the number of questionnaires that could be collected was classified as low. A total of 91 questionnaires can be collected in this study and declared valid so that they can be continued for data processing. Data analysis used in this research is PLS assisted by PLS 3.2.8 software. PLS analysis is carried out in three stages, namely outer model analysis, inner model analysis, and hypothesis testing [21].

\section{RESULT AND DISCUSSION}

\subsection{Result}

\subsubsection{Respondent Characteristics}

The characteristics of respondents are information obtained from respondents whose function is to support the results of data analysis. The characteristics of the respondents may contain some information regarding the demographics of the respondents. In this study, the respondents came from students currently studying at a state university in Malang. Respondents in the study relate to the variables studied related to higher education. The total number of respondents successfully obtained in this study was 91 respondents. Respondents are expected to represent research subjects, namely Brawijaya University, Malang State University, and Malik Ibrahim State Islamic University as state universities in Malang City. The low number of respondents was due to the online distribution and 
limited through social media. Besides, the existence of a pandemic condition is also one of the reasons for the low number of respondents in the study. The limited number of students who are still in Malang City is a problem that must be faced during the pandemic. To overcome the existing constraints, data analysis was carried out with PLS software, which can be used for processing data with a limited number of samples. Besides, testing through PLS software is carried out directly without going through classical assumption tests, and can normalize data automatically.

\subsubsection{Characteristics of Respondents based on $\underline{\text { Gender }}$}

Table 1. Characteristics of Respondents

\begin{tabular}{|l|c|c|}
\hline \multicolumn{1}{|c|}{ Category } & Percentage & Frequency \\
\hline Gender: & 60 & 55 \\
- Female & 40 & 31 \\
- Male & 58 & 53 \\
\hline University & & 11 \\
- Universitas Brawijaya & 12 & 27 \\
- Universitas Negeri & & \\
$\quad$ Malang & 30 & \\
- Universitas Maulana & & \\
\hline
\end{tabular}

(Source: Primary Data, 2020)

Table 1 shows that of the 91 respondents used in this study, 55 of them were female and the remaining 36 were male. The comparison of the two when presented is $40 \%$ versus $60 \%$. The number of women is more dominant in this study. This is partly because more students are studying at state universities in Malang than the number of students.

\subsubsection{Characteristics of Respondents based on Higher Education}

Based on research interests, the measured aspect is where the respondent takes the study. In this case, the respondents are classified into three state universities in Malang City. In the following diagram the blue image represents Brawijaya University, the Orange diagram represents Malang State University, and the gray diagram represents Malik Ibrahim State Islamic University Malang. Based on this figure, it can be seen that the largest respondents as much as $58 \%$ came from Brawijaya University and the least respondents came from the State University of Malang. Most of the respondents come from Brawijaya University because the number of students owned by Brawijaya University is bigger than Malang State University and Malik
Ibrahim State Islamic University.

\subsubsection{Path Diagram Development}

This research model consists of 2 constructs, namely University Satisfaction (X) and University Affiliation (Y) which will be moderated by gender. The step in evaluating the validity and reliability of a construct is done by evaluating the measurement model. The following is a path diagram of the research:

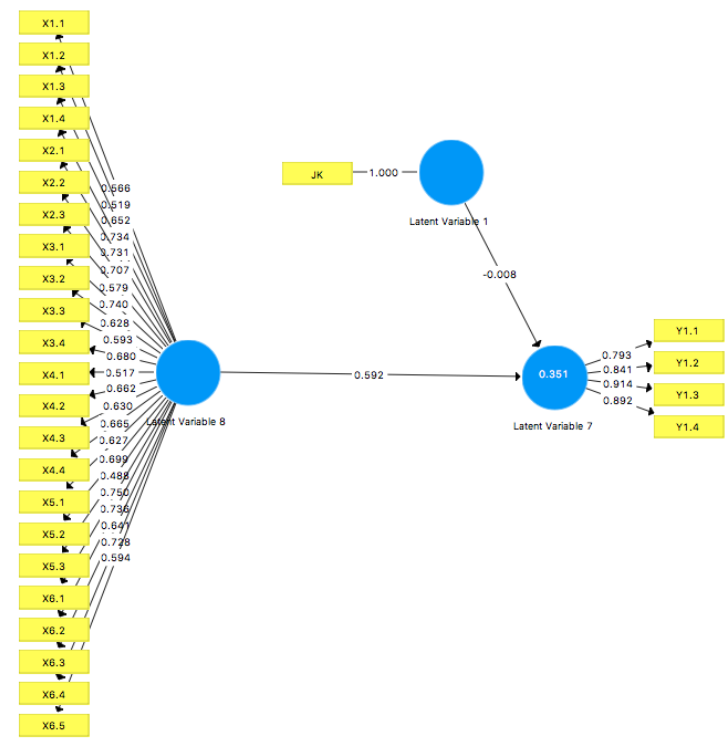

Figure 1. Path Diagram

Source: researcher data, 2020

Based on the path diagram, it can be seen that some items have a value below 0.6. This resulted in the AVE value being below 0.5. As a measurement condition, the model is feasible when the AVE value is above 0.5. One of the ways to deal with these problems is by eliminating items that have a value below 0.6. According to [21] items that have a value below 0.6 must be removed from the model under study. then the step taken is to delete items whose value is above 0.6 from the lowest. Furthermore, the path diagram after removing the item looks like the image below. 


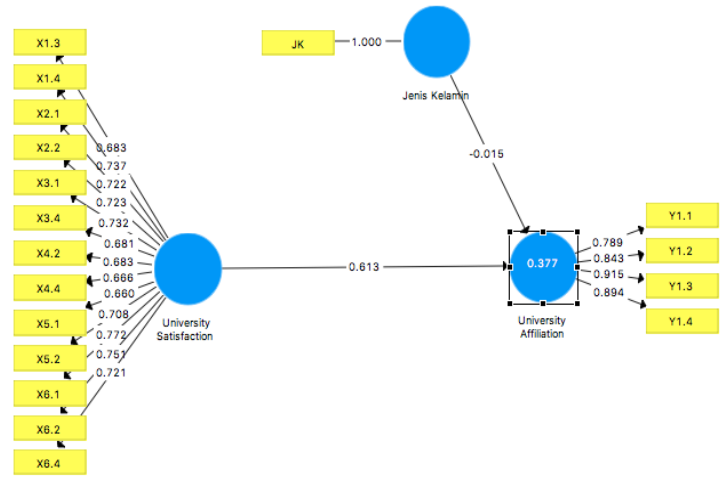

Figure 2. Validity and Reability

Source: researcher data, 2020

\subsubsection{Outer Model Evaluation}

Outer Model Evaluation is carried out through Confirmatory Factor Analysis (CFA) by testing the validity and reliability of latent constructs. Latent construct testing is done by looking at the Convergent Validity and Discriminant Validity values of the construct. Convergent validity is indicated by the value stated on the loading factor. In measuring convergent validity, all research items have an outer model value above 0.6. After measuring convergent validity, the next step is to measure the reliability of each variable. Reliability is measured through the Cronbach alpha value and reliability composite. The Cronbach alpha value must be above 0.7 and the AVE value must be above 0.5. Based on the measurements made, the Cronbach alpha value exceeds 0.63 and the AVE value is greater than 0.5. Thus all items in the study. From the calculation of Chronbach's Alpha and Composite Reliability, all indicators are reliable in measuring their latent variables.

\subsubsection{Coefficient of Determination (R2)}

The coefficient of determination determines the contribution of the University Satisfaction (X1) variable to explain the University Affiliation (Y) variable. The test results of the coefficient of determination show that the effect of university satisfaction on university affiliation is 0.377 or $37.7 \%$. The remaining $62.3 \%$ is explained by other variables not examined in this study.

\subsubsection{Hypothesis test}

Tabel 2. Path Coeficient

\begin{tabular}{|l|c|c|c|}
\hline & $\begin{array}{c}\text { Path } \\
\text { Coefficient }\end{array}$ & S.E & P-Values \\
\hline $\begin{array}{l}\text { University } \\
\text { Satisfaction -> } \\
\begin{array}{l}\text { University } \\
\text { Affiliation }\end{array}\end{array}$ & 0,613 & 0,045 & 0,000 \\
\hline
\end{tabular}

Based on table 2, the $t$ value of $X(13.611)>1.96$ and the P-value $(0.000)<0.05, \mathrm{H} 1$ is accepted. This shows that the University Satisfaction $(\mathrm{X})$ variable has a significant effect on the University Affiliation $(\mathrm{Y})$ variable. These results are in line with the research of [9], and [13].

\subsubsection{Multi-Group Analysis Testing}

Apart from this research was conducted to determine the effect of the University Satisfaction (X) variable on the University Affiliation (Y) variable, as well as to determine the differences in respondents' perceptions based on gender, namely students and female students who took education at Brawijaya University, State University of Malang, and Maulana Malik Ibrahim University. The following are the results of the Multi-Group Analysis test shown in Table 3. Based on the parametric test using multi-group analysis as shown in table 3, the value of $t$ count $X$ against $Y$ by comparing directly the answers of student and female respondents has no difference.

This is shown by the $t$ value less than 1.96 with a standard error of $5 \%$ and a probability value of more than 0.05 . These results also show that there are no differences in the perceptions and behavior of students in making the university an affiliate for themselves. Thus, all respondents have the same perception of the effect of University Satisfaction at University Affiliation.

\subsection{Discussion}

The university is a space for students to carry out their studies. Students' pride in their university will greatly impact the university. This sense of pride is applied to the use of icons or items with symbols of affiliation. The home university is part of its affiliation. In previous research conducted by [1], the same thing can be shown by employees who work for companies. Employees who perceive the company as a meaningful affiliate will voluntarily and proudly display or use affiliates' goods and symbols. This 
study tries to link the same thing between employees at the company but by using the subject of higher education. In the business world, employees are part of the company entity that cannot be separated. This also occurs in the educational environment, that students are part of an inseparable university entity. So that in this case students at a certain point voluntarily use products or symbols of the university which are affiliated

This behavior can be realized when students have gotten what they expected. Satisfaction in encouraging loyal behavior and other positive behavior is very necessary. Satisfaction can be used as a measure in determining student pride. Higher education as an institution that becomes a space for students to study, then this satisfaction can be provided through all services provided by the university. The university's ability to handle student problems and provide good service to students will lead to feelings of satisfaction in students. Student satisfaction will encourage them to be proud of their affiliates.

In this study, it has been proven that the effect of university satisfaction has a significant effect on university affiliation. The results of this study support several previous studies which state that university satisfaction has an important role in building university affiliation [9], and [13]. In the application, the university which is an affiliate for students must provide the best service to students. Students' pride in their affiliation will be useful for the university as an affiliate.

The behavior is shown by using products or attributes that contain university symbols. The use of products, attributes, and even symbols can reflect the image of the university. A positive image will indirectly give a positive impression to the public. This at the same time can be an indirect marketing agent and will increase the attractiveness of the university. Besides, this study also wanted to measure the role of gender in moderating university satisfaction at university affiliations. Venus's theory states that each gender will determine the role of masculine and feminism. The feminine and masculine temperaments of each gender have different proportions. This can be shown by dressing and using supporting accessories when traveling. This study aims to determine gender perceptions of university satisfaction with university affiliation. The results show that there is no difference in gender perceptions for both men and women. Men and women have the same perception of seeing the effect of university satisfaction on university affiliation. So that gender does not moderate the effect of university satisfaction at university affiliation. This shows that both students and students when they are satisfied with the services provided by the university, they will volunteer to use the university's products, attributes, or symbols as affiliates.

\section{CONCLUSIONS, SUGGESTIONS AND LIMITATIONS}

Our research found several things, first, University satisfaction has contributed to the formation of university affiliations. Universities as student affiliations must provide satisfaction with the services provided. Second, gender does not have a moderating effect on university affiliation. This means that love for the university does not look at students or female students. Those who are satisfied with the university's services will voluntarily continue to use the university's products, attributes, or symbols.

This study has several deficiencies that can be developed in further research studies. Several things become weaknesses in research such as the limitations of the variables discussed, university affiliation is influenced by many things, not only related to university satisfaction. so that further researchers can go deeper and discuss other variables or combine university affiliation variables with other variables. This study has a small number of respondents and data collection was carried out during a pandemic. If the sample is enlarged and the data collection process is carried out under normal conditions it will be possible to increase the number of respondents studied. This allows for different results, because of the possibility that the variants of the respondent's answer can change and are higher. This research was conducted limited to state universities in Malang City. Further researchers can develop in universities with a larger scope. Besides, research results that have differences with previous research can be explored more deeply and developed in further research.

\section{AUTHORS' CONTRIBUTIONS}

There are two author's contributions to this research:

a. Universities as student affiliations must provide satisfaction with the services provided. 
b. Gender does not have a moderating effect on university affiliation. This means that love for the university does not look at students or female students. Those who are satisfied with the university's services will voluntarily continue to use the university's products, attributes, or symbols

\section{ACKNOWLEDGMENTS}

We thank to Lembaga Penelitian dan Pengabdian Kepada Masyarakat (LPPM), Brawijaya University for financial support and research team for help distribution questionnaire.

\section{REFERENCES}

[1] M. S. Balaji, S. K. Roy, and S. Sadeque, "Antecedents and consequences of university brand identification," J. Bus. Res., vol. 69, no. 8, pp. 3023-3032, 2016, doi: 10.1016/j.jbusres. 2016.01. 017.

[2] A. L. Stephenson and D. B. Yerger, "Does brand identification transform alumni into university advocates?," Int. Rev. Public Nonprofit Mark., vol. 11, no. 3, pp. 243-262, 2014, doi: 10.1007/s12208-014-0119-y.

[3] J. Hemsley-Brown and S. Goonawardana, "Brand harmonization in the international higher education market," J. Bus. Res., vol. 60, no. 9, pp. 942-948, 2007, doi: 10.1016/j.jbusres. 2007.01.019.

[4] R. Casidy, "The role of brand orientation in the higher education sector: a student-perceived paradigm," Asia Pacific J. Mark. Logist., vol. 25, no. 5, pp. 803-820, 2013, doi: 10.1108/APJML-06-2013-0069.

[5] F. Mael and B. E. Ashforth, "Alumni and their alma mater: A partial test of the reformulated model of organizational identification," J. Organ. Behav., vol. 13, no. 2, pp. 103-123, Mar. 1992, doi: 10.1002/job.4030130202.

[6] J. Douglas, A. Douglas, and B. Barnes, "Measuring student satisfaction at a UK university," Qual. Assur. Educ., vol. 14, no. 3, pp. 251-267, Jul. 2006, doi: 10.1108/096848806 10678568 .

[7] N. H. Head, B. Management, S. Bhamani, and B. Management, I j c r b, no. 2009, pp. 332-341, 2012.
[8] P. M. Blau, Exchange and power in social life. New Brunswick, NJ: Transaction Publishers., pp. 1-352, 1964.

[9] T. Gruber, S. Fuß, R. Voss, and M. Gläser-Zikuda, Examining student satisfaction with higher education services, Int. J. Public Sect. Manag., vol. 23, no. 2, pp. 105-123, Mar. 2010, doi: 10.1108/09513551011022474.

[10] J. W. Johnson and A. Rapp, A more comprehensive understanding and measure of customer helping behavior, J. Bus. Res., vol. 63, no. 8, pp. 787-792, 2010, doi:10.1016/j.jbusres. 2008.03. 006.

[11] R. W. Permana, Malang Sebagai Kota Pendidikan Sejak Masa Penjajahan Belanda., Malang Merdeka, Malang, 2016.

[12] F. Hilmi, Alasan Kenapa Kuliah Di Malang, Idn Times, Malang, 2017.

[13] B. D. Oja, J. R. Bass, and B. S. Gordon, Conceptualizing employee identification with sport organizations: Sport Employee Identification (SEI), Sport Manag. Rev., vol. 18, no. 4, pp. 583-595, 2015, doi: 10.1016/j.smr. 2015.02.002.

[14] L. Harvey and D. Green, Defining Quality, Assess. Eval. High. Educ., vol. 18, no. 1, pp. 934, Jan. 1993, doi: 10.1080/0260293930180102.

[15] M. Marzo-Navarro, M. Pedraja-Iglesias, and M. P. Rivera-Torres, Measuring customer satisfaction in summer courses, Qual. Assur. Educ., vol. 13, no. 1, pp. 53-65, 2005, doi: $10.1108 / 09684880510578650$.

[16] P. Sander, K. Stevenson, M. King, and D. Coates, University Students' Expectations of Teaching, Stud. High. Educ., vol. 25, no. 3, pp. 309-323, 2000, doi: 10.1080/030750700501 93433.

[17] D. D. Gremler and M. A. McCollough, Student Satisfaction Guarantees: An Empirical Examination of Attitudes, Antecedents, and Consequences, J. Mark. Educ., vol. 24, no. 2, pp. 150-160, 2002, doi: 10.1177/027753024002 008.

[18] F. M. Hill, Managing service quality in higher education: the role of the student as primary consumer, Qual. Assur. Educ., vol. 3, no. 3, pp. 10-21, Sep. 1995, doi: 10.1108/096848895100 93497. 
[19] J. Giese and J. Cote, Defining consumer satisfaction, Acad. Mark. Sci. Rev., vol. 2000, no. January 2000, p. 1, 2000, [Online]. Available:

https://www.researchgate.net/publication/23535 7014.

[20] K. M. Elliott and D. Shin, Student Satisfaction: An alternative approach to assessing this important concept, J. High. Educ. Policy Manag., vol. 24, no. 2, pp. 197-209, Nov. 2002, doi: $10.1080 / 1360080022000013518$.
[21] A. S. Hussein, Penelitian bisnis dan manajemen menggunakan partial least squares (PLS) dengan smart PLS 3.0, Modul ajar. Fakultas Ekonomi dan Bisnis, Universitas Brawijaya, 2015. 